\begin{tabular}{c} 
21 (1), 2020, 67-77 \\
Jurnal Pendidikan MIPA \\
e-ISSN: 2550-1313|p-ISSN: 2087-9849 \\
http://jurnal.fkip.unila.ac.id/index.php/jpmipa/ \\
\hline JURNAL \\
PENIIIKAN MIPA
\end{tabular}

\title{
Analysis of Indonesian Students' Error in Solving Mathematical Literacy Problems Based on PISA 2015 Results
}

\author{
Santy Setiawati ${ }^{1}$, Tatang Herman ${ }^{2}$, Al Jupri ${ }^{2}$ \\ ${ }^{1}$ Department of Mathematics Education, Universitas Lampung, Indonesia \\ ${ }^{2}$ Department of Mathematics Education, Universitas Pendidikan Indonesia, Indonesia
}

\begin{abstract}
This study aims to describe the students' error in solving mathematical literacy problems with focused on level 3 and 4 based on PISA 2015. Qualitative research was used in this study with a descriptive approach. The subjects of this study were 61 students at seventh grade consisted of 28 students from SMPN 14 Bandung and 33 students from SMPN 9 Bandung. The instrument consisted of four questions designed and interview guidelines. Data were analyzed descriptively based on written test results and interviews to confirm students' work. The results of this study showed that $65.3 \%$ of students made mistakes in solving mathematical literacy level 3 and $73.68 \%$ of students made mistakes in solving mathematical literacy level 4. Students' error that arise in solving these mathematical literacy problems are understanding the problem and choosing the information to get a solution. Based on the results, researcher suggest that the preparation of sentences in the mathematical literacy problem, it should be emphasized with the precise sentences, so that the purpose of the problem is well understood by students.
\end{abstract}

Keywords: students' error, mathematical literacy problems level 3 and 4, PISA 2015 results, junior high school students.

Abstrak: Tujuan dari penelitian ini adalah mendeskripsikan kesalahan siswa dalam menyelesaikan soal kemampuan literasi matematis level 3 dan 4 berdasarkan PISA 2015. Jenis penelitian ini adalah penelitian kualitatif dengan pendekatan deskriptif. Subjek penelitian ini adalah 61 siswa SMP kelas VII, yang terdiri dari 28 siswa SMPN 14 Bandung dan 33 siswa SMPN 9 Bandung. Instrumen penelitian terdiri dari empat butir soal kemampuan literasi matematis dan pedoman wawancara. Data dianalisis secara deskriptif berdasarkan hasil tes tertulis dan wawancara untuk mengkonfirmasi jawaban siswa. Hasil penelitian menunjukkan bahwa 65,3\% siswa yang melakukan kesalahan dalam menyelesaikan soal literasi matematis level 3 dan 73,68\% siswa yang melakukan kesalahan dalam menyelesaikan soal literasi matematis level 4. Kesalahan siswa yang muncul dalam menyelesaikan soal literasi matematis ini terkait memahami masalah dan memilih informasi untuk memperoleh solusi. Berdasarkan hasil penelitian, peneliti menyarankan bahwa dalam menyusun kalimat dalam soal matematika literasi, harus ditekankan dengan kalimat yang tepat, sehingga maksud dari soal tersebut mudah dipahami dengan baik oleh siswa.

Kata kunci: kesalahan siswa, literasi matematis level 3 dan 4, hasil PISA 2015, siswa SMA.

Santy Setiawati

Email: santy.setiawati@fkip.unila.ac.id
DOI: http://dx.doi.org/10.23960/jpmipa/v21i1.pp67-77

Received: 11 February March 2020

Accepted: 12 June 2020 


\section{- INTRODUCTION}

Mathematics is a very important thing to understand, because mathematics is a basic science in all fields of science. Having mastery of a mathematics can help someone to solve the problems in daily life. In accordance with Johar (2012) that knowledge and understanding of mathematical concepts is very important, but more importantly is the ability to solve problems faced in everyday life. Thus, it is important for students to have mathematical literacy ability (Vila \& Sanz, 2013).

Mathematical literacy was launched by NCTM in 1989 as one of the visions of mathematics education which is to become literate in mathematics. In accordance with Tariq, Qualter, Roberts, Appleby, \& Barnes (2013) in their research that PISA problems adopt the concept of literacy. In fact, PISA study stated that, based on International results, mathematical literacy ability of Indonesian students are still low in the ranking and proficiency level (OECD, 2010; OECD, 2014; OECD, 2016). Previous study also revealed that mathematical literacy ability students are still low (Mahdiansyah \& Rahmawati, 2014; Wulandari, Turmudi, \& Hasanah, 2015; Turner, 2016; Asmara, Waluya, \& Rochmad, 2017). In the study of Wulandari, Turmudi, \& Hasanah (2015) conducted in 3 junior high schools in Bandung stated that the mathematical literacy ability of junior high school students at level 4 and level 5 mathematical literacy achievements are still low. Based on the results of these studies, mathematical literacy abilities of students for level 4 is $45.65 \%$ (Wulandari, Turmudi, \& Hasanah, 2015) which categorized as low level of literacy.

Students have a difficulties or made an error in solving mathematical literacy problems. Stacey (2011) in her research study stated that Indonesian students not good enough in solving problems about change and relationship. Based on the interviews conducted by researcher with three students of seventh grade about quantity problems, students do not understand the purpose of the questions to find the solution. As Anisah, Zulkardi, \& Darmawijoyo (2011) points out that students have difficulty understanding the quantity problems, so it seems that the students' mathematical literacy in reading ability is still low.

Aspects of mathematical literacy include mathematical process and mathematical content knowledge (OECD, 2016). Mathematical process in mathematical literacy (OECD, 2016) i.e., (1) formulating a mathematical situation, (2) employing mathematical concepts, facts, procedures and reasoning, (3) interpreting, applying and evaluating mathematical results. The mathematical process on mathematical literacy was used as an indicator of mathematical literacy ability in this study. Content knowledge in PISA 2015 is interpreted as content or mathematics lessons learned in school. There are 4 mathematical content at PISA 2015, that are (1) change and relationship, (2) space and shape, (3) quantity, and (4) uncertainty and data (OECD, 2016). In this study, mathematical content used were change, relationship and quantity.

Proficiency in mathematical literacy according to PISA study is consist of 6 levels (OECD, 2016). This study discusses proficiency of mathematical literacy level 3 and 4. Description of the two levels of mathematical proficiency based on PISA 2015 (OECD, 2016), i.e., students can typically do: (1) at level 3, students can carry out the procedure in solving problems and can choose or apply simple problem solving strategies and communicate the results of their interpretations, (2) at level 4, students can work effectively with models and can choose and integrate different representations, then connect them to the real world. Students can provide explanations and communicate arguments based on student interpretations and actions. 
The proficiency of mathematical literacy is still low and the cause students made an error in solving mathematical literacy problems is an important issue in mathematics education. Needed an attention and found out the conditions in depth what are the things that cause mathematical literacy ability are still low and many errors experienced by students in solving the problem. Therefore, in the current study, this research aims to describe error of junior high school students' in solving mathematical literacy problems level 3 and 4.

\section{- METHOD}

To address the research question, we conducted a qualitative research. Qualitative research is research that intends to understand the phenomena about what is experienced by research subjects, for example behavior, perception, motivation, action, etc., holistically and described in words and language, in a context specifically natural and utilize various natural methods (Moleong, 2016). Qualitative research was used in this study with a descriptive approach. As Clandinin \& Connelly points out that at the end of the research, researchers must combine with the narrative style about participant point of view and researchers own lives (Creswell, 2016).

The subjects of the study were 61 seventh grade students in Bandung consisted of 28 students from SMPN 14 Bandung and 33 students from SMPN 9 Bandung. An individual written test on mathematical literacy problems was administered, followed by interviews. 26 of 61 students were interviewed afterward. The instrument consisted of four questions and interview guidelines. The questions were designed based on PISA problems on the proficiency of mathematical literacy level 3 and level 4. A written test questions were considered by two supervisors, three mathematics teacher in junior high school and some seventh grade students for the readability of the questions. Then, a written test questions were tested to get the validity of items and reliability.

Written test is required to collect data or information about the students' work and the whole steps of students' answer in solving the mathematical literacy problems. Furthermore, interviews were conducted with students to strengthen the analysis of students' error in solving mathematical literacy problems level 3 and level 4. Data analysis technique is the process of collected and arranged data systematically from students' work and data from interviews to confirm students' work with the completing steps that are in students' mind.

\section{- RESULT AND DISCUSSION}

\section{Description of students making an error in solving mathematical literacy problems level 3 and 4}

There are students who made an error in solving mathematical literacy problems level 3 and level 4 . Table 1 presents the percentage and number of students who made errors in solving mathematical literacy problems.

Table 1. Percentage and number of students who made mistakes in solving mathematical literacy problems

\begin{tabular}{lccccc}
\hline School name & $\begin{array}{l}\text { Number of } \\
\text { students }\end{array}$ & Level & $\begin{array}{l}\text { Question } \\
\text { number }\end{array}$ & $\begin{array}{l}\text { Percentage of } \\
\text { students with } \\
\text { wrong answer } \\
(\%)\end{array}$ & Average \\
\hline SMPN 14 & 28 & 3 & 1 & $53.5 \%$ & $65.3 \%$ \\
\hline
\end{tabular}




\begin{tabular}{|c|c|c|c|c|c|}
\hline \multicolumn{2}{|l|}{ Bandung } & & 2 & $71.4 \%$ & \\
\hline SMPN 9 & \multirow{2}{*}{33} & & 1 & $75.7 \%$ & \\
\hline Bandung & & & 2 & $60.6 \%$ & \\
\hline SMPN 14 & \multirow{2}{*}{28} & \multirow{4}{*}{4} & 3 & $78.5 \%$ & \multirow{4}{*}{$73.68 \%$} \\
\hline Bandung & & & 4 & $67.8 \%$ & \\
\hline SMPN 9 & \multirow{2}{*}{33} & & 3 & $75.7 \%$ & \\
\hline Bandung & & & 4 & $72.7 \%$ & \\
\hline
\end{tabular}

\section{Analysis of students' responses}

Students were asked to solve four questions of mathematical literacy problems. After students complete the given problem, they also interviewed to clarify their answers. Based on the analysis of literacy mathematics test and interview results, the following describes the analysis of students' responses.

The first problem is the relationship of the distance ( $s)$, speed $(v)$, and time $(t)$ of a car is expressed by the formula $s=v \times t$. The formula be used for calculate of Widi's trip from Jakarta to Bandung with a distance of $150 \mathrm{~km}$. Circle Yes or No in the following statement based on the information above and write down your reason or strategy in the reason column.

Table 2. Students answer sheet

\begin{tabular}{lll}
\hline Statement & Is this statement true? & Reason \\
\hline If Widi departs from & Yes/No & \\
Jakarta at 07.00 WIB and & \\
arrives in Bandung at 09.30 & & \\
WIB, then Widi's car speed & & \\
is $50 \mathrm{~km} /$ hour. & & \\
\hline
\end{tabular}

The first question is change and relationship content. The indicator of mathematical literacy are (1) employing mathematical concepts, facts, procedures and reasoning, (2) interpreting, applying and evaluating mathematical results (OECD, 2016). The first question was included in the proficiency level 3 of mathematical literacy, because students were asked to carry out procedures properly, where the intended procedure is the application of formulas, then students were also asked to be able to communicate with arguments based on student actions in operating calculations (OECD, 2016). Here is the students' answer for the first question as in figure 1.

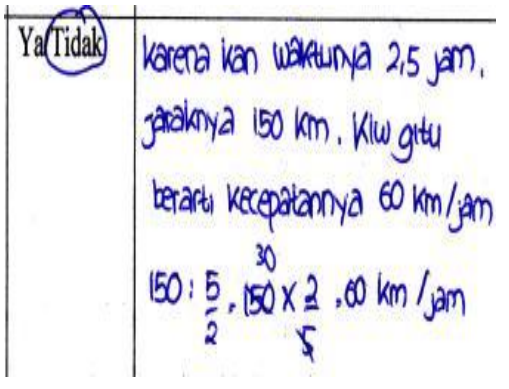

(a)

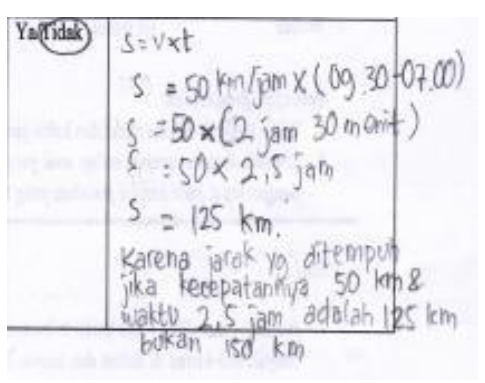

(b)

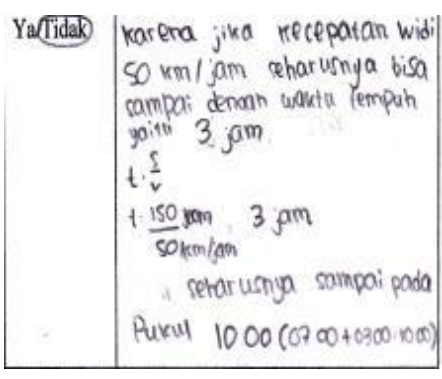

(c)

Figure 1. The answer of (a) Dhia, (b) Nabila, and (c) Ali for the first question. 
Students works in figure 1 showed that students have fulfilled the indicator of mathematical literacy ability. In Figure 1a showed the results of the answer to first question which has done the procedure with the formula and evaluates the statement that the speed is wrong, and the speed of the car should be $60 \mathrm{~km} / \mathrm{hr}$. Figure $1 \mathrm{~b}$ was the result of the student's answer which shows that he solved the problem with evaluating the distance. Figure 1c was the result of student's answer who complete the problem with evaluating the time.

Although the results of student answers to solve the first question fulfill the process of mathematical literacy ability, but there is an error in evaluating the statement on the question, as in figure $1 \mathrm{~b}$ and 1c. Nabila solve this problem by evaluating the distance of the car as in figure $1 \mathrm{~b}$. Nabila said that she was finished it with a formula that she knew, because she had studied formulas like that before. While Ali admitted that he was wrong in solving problems because he was in a hurry to solve it, as in Figure 1c.

The first question seems to illustrate why the score of Indonesian students' mathematical literacy in the International is low, it seems that because students solve the problems of mathematical literacy with the steps they want, not with the steps ordered by the problems. This error turns out to be categorized into the category of Newman's error, which is understanding the problem, because students are not able to understand what is known and asked (Singh, Rahman, \& Hoon, 2010). Prakitipong \& Nakamura (2006) also revealed that "most student errors occur in understanding problems for structured questions".

There were students made an error when solve the problem, so the results were wrong. The errors seen in choosing information, which is the speed. Figure 2 presents an example of the results of student's answers. Student made mistakes caused by inaccuracies in reading the questions. According to Sari's research results (2013) which reveal that "the causes of errors can be caused by inaccuracies in reading, inability to see ordinary problems with new or unusual ways or approaches".

\begin{tabular}{|c|c|}
\hline $\begin{array}{l}\text { Apakah } \\
\text { pernyataan } \\
\text { ini benar? }\end{array}$ & $\begin{array}{ll}\text { Alasan } & \\
S=150 \mathrm{~km} & V=50^{\circ} \mathrm{T} \\
t=150 \mathrm{men}(\mathrm{t} & =1 \mathrm{~km} \mathrm{~J} \mathrm{Jam}\end{array}$ \\
\hline Ya(ridak & $\begin{aligned} t & =0930 \\
& \frac{0700}{2.30} / \text { isomenit } \\
s= & 150 \mathrm{hm} \\
v & =5: T \\
& =1 \mathrm{hm} / \mathrm{Jam}\end{aligned}$ \\
\hline
\end{tabular}

Figure 2. The answer of Gloria for the first question.

The second problem is the following ingredients were needed to make 1 pan of macarons. One pan containing 10 macarons cakes. Macarons cake ingredients for 1 pan: $300 \mathrm{~g}$ almond flour, $300 \mathrm{~g}$ powdered sugar, $110 \mathrm{~g}$ egg whites, $1 \frac{1}{2}$ tea spoon food coloring, $300 \mathrm{~g}$ sugar, $75 \mathrm{~g}$ water. Bela has prepared $1800 \mathrm{~g}$ almond flour, $1500 \mathrm{~g}$ powdered sugar, 440g egg whites, 2 bottle food coloring $(1$ bottle $=30 \mathrm{ml}), 1550 \mathrm{~g}$ sugar and $400 \mathrm{~g}$ water. How many macaroon cakes will Bela make? Explain your reasons. (Hint: $1 \frac{1}{2}$ tea spoon $=7,5 \mathrm{ml}$ ). 
The second question is quantity content. The indicator of mathematical literacy, i.e. (1) employing mathematical concepts, facts, procedures and reasoning, (2) interpreting, applying and evaluating mathematical results (OECD, 2016). The second question was included in proficiency mathematical literacy level 3, because in this problem students can carry out procedures well, choose, implement strategies to solve simple problems, and communicate the results (OECD, 2016). Students' work for the second question as in figure 3.

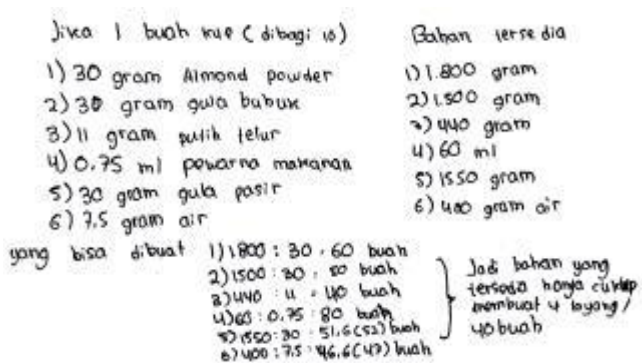

(a)

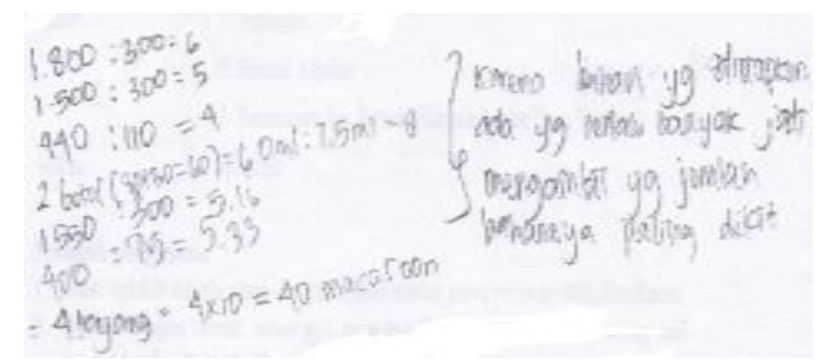

(b)

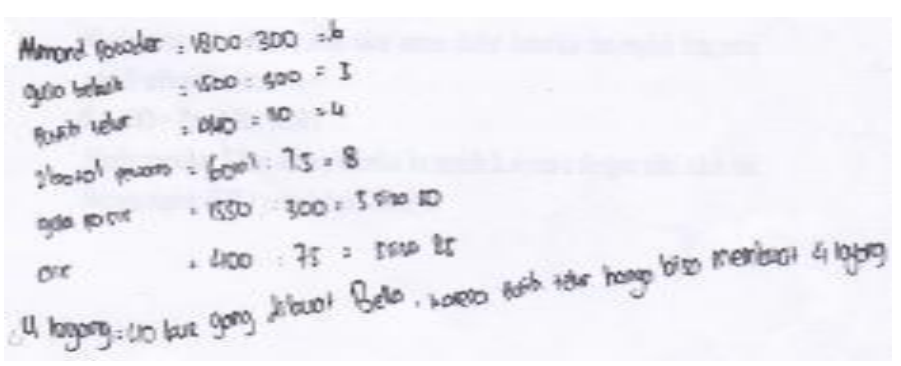

(c)

Figure 3. The answer of (a) Ali, (b) Rachel, and (c) Fira for the first question.

The results of students' work in Figures 3 have implemented procedures or used facts, mathematical rules in finding solutions (OECD, 2016). In the step of applying concepts, facts, procedures and mathematical reasoning or in the process of applying facts, rules, mathematical algorithms to find solutions in the second question, three different solutions were found.

Students solve the problem were similar in the solutions. In Figure 3a, Ali suppose the ingredients needed for 1 cake first, while in the problem the ingredients needed for 10 pieces of cake or equal to 1 pan. So, Ali divided 10 of the ingredients needed. Furthermore, the calculations were similar as those done as in Figure $3 \mathrm{~b}$ and $3 \mathrm{c}$. In Figure 3b, the answer of Rachel's work, the differences in writing the results, it was written 1550:300 $=5,16$ and 400:75 $=5,33$. While in Figure 3c, the answer of Fira's work was written 1550:300 $=5$ remaining 50 and 400:75 $=5$ remaining 25 . Those three results in Figure 3, also have fulfilled the process of interpreting the mathematical results, where the conclusion is that the ingredients prepared by Bela were sufficient to make 4 baking pans or 40 cakes.

There are also students who made an error in the second question, so the results of the answers are less precise as in figure 4. 


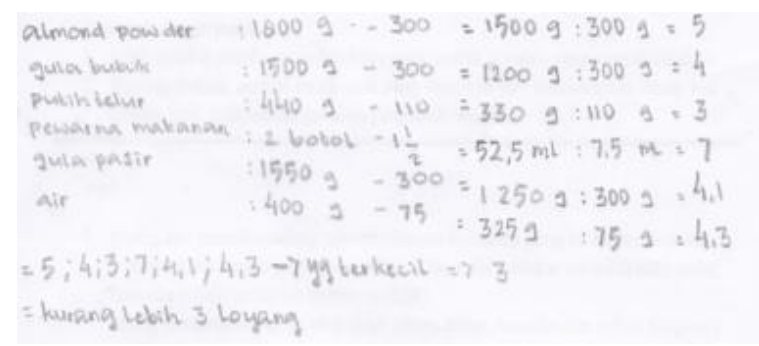

Figure 4. The answer of Nazarina for the second question.

It seems that student made an error in the process of ingredients prepared minus ingredients macaron for one pan. After being confirmed through interviews, student seemed to understand this problem, which is she was explained again the steps to solve it. However, it turns out student thought the ingredients for making 1 pan had to be made first, after that found out how many baking pans to make again. Student' errors was understanding the problem. This error turns out to be categorized into the Newman error category, namely in understanding the problem (Singh, Rahman, \& Hoon, 2010). In line with Wijaya, Heuvel-Panhuizen, Doorman, \& Robitzcsh (2014) that $38 \%$ of total students have errors in understanding the meaning of context-based questions.

The third problem is Here you see a picture of stones stacks.

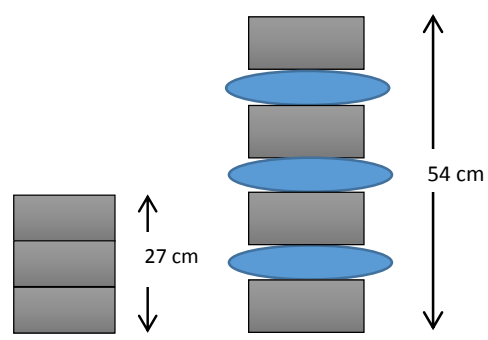

The picture above is two stones stacks that have different heights. Also, two shapes of stones which is rectangular and oval. What is the heights of each rectangular stone and oval stone? Explain your strategy.

The third question is change and relationships content. The indicators of mathematical literacy are (1) formulating mathematical situations, (2) applying mathematical concepts, facts, procedures and reasoning, and (3) interpreting, applying and evaluating mathematical results (OECD, 2016). The third question was included in the proficiency mathematical literacy level 4 , because in this problem students must be able to work effectively with mathematical models that are associated with real-world situations. Students can also provide explanations and communicate their actions (OECD, 2016). Students' work for the second question as in figure 5.

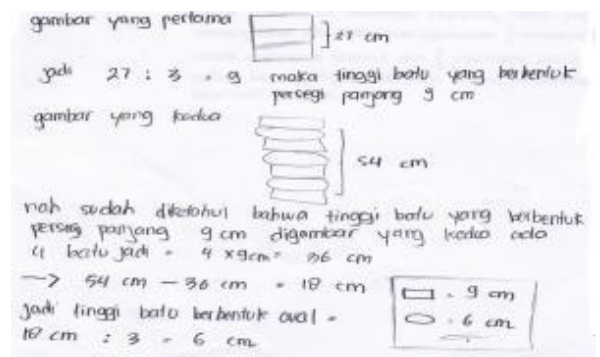

Figure 5. The answer of Tengku for the third question. 
The results of student's work in Figure 5 show that students only carry out the process of applying concepts, facts, procedures and mathematical reasoning. Students understand the purpose of the problem, but in the solution students use direct calculation. In the first stones stacks, the height of the stones stacks is $27 \mathrm{~cm}$, there are 3 rectangular stones, so students divide directly 27 by 3 equals to $9 \mathrm{~cm}$. It seems that the height of the stones stacks and the number of stones in the stacks is obvious, so students immediately conducted a divide operation to find out the height of 1 stone.

The results of student's work in Figure 5 did not indicate the existence of a mathematical model which is one of the processes of mathematical literacy ability, that is formulating mathematical situations (OECD, 2016). Algebra problems relate to symbols, variables, and equations where the method of solving does not directly have rules or algorithms that can immediately be used to determine the answer (Aini \& Siswono, 2014). An errors made by students in working the third question. The student assumed that the two stacks of stones in the problem are different and unrelated. The following is an example of the results of student's work as in figure 6 .

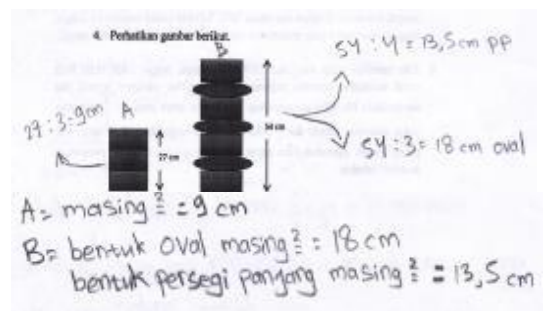

Figure 6. The answer of Akmal for the third question.

The results of the student's work in Figure 6 assumed that the stones stacks were different, even the student gave notes to the two stones stacks in the question, that is A and B. The first steps taken by student, as in Figure 6, similar to student's work as in Figure 5, which is divides $27 \mathrm{~cm}$ by 3 equals to $9 \mathrm{~cm}$. However, the next step, for the height of the rectangular stone on the second stack, student divides $54 \mathrm{~cm}$ with 4 equals to $13.5 \mathrm{~cm}$ and divides $54 \mathrm{~cm}$ with 3 equals to $18 \mathrm{~cm}$ for the height of the oval shaped stones. After being confirmed through interviews, Akmal said that the height of the stacks was different, in the second stacks have more stones than in the first stacks. Then in the first stacks there were no oval stones.

Student's error in solving problems by giving assumptions to the questions that are not in accordance with the problems and errors in applying other mathematical concepts to solve problems. Student thoughts on the picture of stacks stones that look different made student made an error in calculating the height of an oval stones. This error turns out to be categorized into the Newman error category, that is an error in understanding the problem (Singh, Rahman, \& Hoon, 2010), because students mistakenly interpret the picture in problem. In accordance with White (2010) revealed that "the first mistake students make is to understand the problem".

The fourth problem is: Ani has a pack of candies. Cika has 4 more candies than Ani. Total of Ani and Cika candies is 48 candies. How many each of Ani's candies and Cika's candies? Explain your answer!

The fourth question is change and relationship content. Indicators of mathematical literacy ability, that are (1) formulating mathematical situations, and (2) applying concepts, facts, procedures and mathematical reasoning (OECD, 2016). This problem was included in the proficiency of mathematical literacy level 4 , because this problem 
asks students to work effectively with mathematical models that are related to realworld situations, and students are asked to provide explanations and communicate their completion steps (OECD, 2016). Students' work for the fourth question as in figure 7.

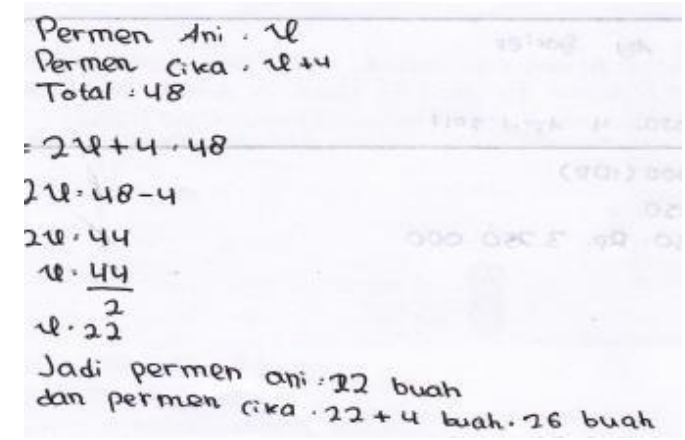

Figure 7. The answer of Ali for the fourth question.

The results of the students' work in Figure 7 showed that they have fulfilled the process of mathematical literacy ability, which is to formulate mathematical situations by writing a mathematical model by bringing up an equation (OECD, 2016). Although in writing the description of a variable it is not precise. In the student' answer in Figure 7 was written "Ani's candy: $x$ ", where the variable is a symbol that represents a number and size of a particular object. So, the variable in this problem should be written "the lots of Ani candy $=x$ ". The process of applying concepts, facts, procedures and mathematical reasoning has also been fulfilled in the results of student's answers in figure 7. There are students' work showed that students understand the purpose of the problem, but they use direct calculations. Figure 8 is an example of the results of students' answer.

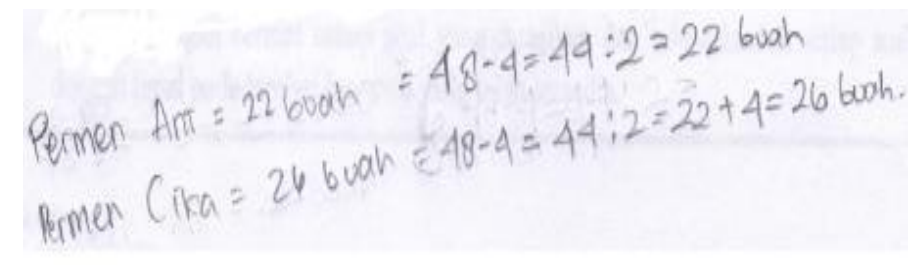

Figure 8. The answer of Rachel for the fourth question.

It seems that student was guessing a number that fits the context of the problem. Student was using logical so that it gives correct answers. Children start from counting concrete objects and dealing with numbers to count and deal with numbers abstractly (Pietersen, 2006). To solve the fourth question, students grade VII still count it, because there was a number that can be counted. There are students who made an error in solving the fourth question, that is students who solve it with their own way or other mathematical concepts. Figure 9 below presents an example of the results of student answers.

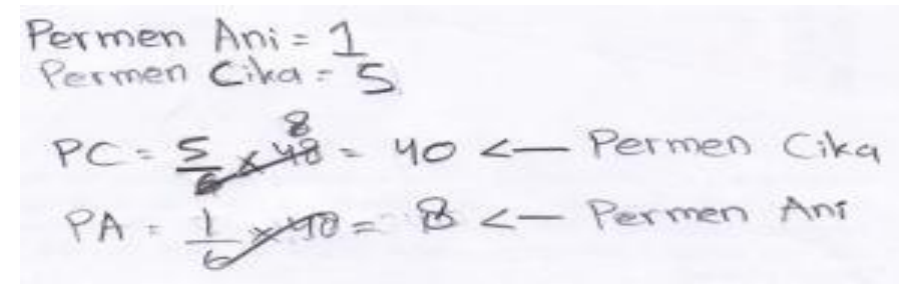

Figure 9. The answer of Akmal for the fourth question. 
After being interviewed, student said the thing that caused him to solve the fourth question as in Figure 9 was the mathematical concept he remembered was proportion concept. Apparently, this mathematical literacy context problem has been given briefly before on proportion concept, so that he brought up to solve these problem. As in Figure 9, student can understand mathematical concepts, but cannot apply them in solving realworld problems (Firdaus, Wahyudin, \& Herman, 2017). Thus, the error that arises was an error applying another mathematical concept to solve algebra problem. This error turns out to be categorized into the Newman error category, that is understanding the problem (Singh, Rahman, \& Hoon, 2010). Students can read the questions properly and correctly but cannot interpret the sentences in the problems. An error that occur can be in the form of misunderstanding in choosing information on the problem (Wijaya, Heuvel-Panhuizen, Doorman, \& Robitzcsh, 2014).

\section{- CONCLUSION}

The results of this study showed that $65.3 \%$ of students made mistakes in solving mathematical literacy level 3 and $73.68 \%$ of students made mistakes in solving mathematical literacy level 4. Students' error that arise in solving these mathematical literacy problems are understanding the problem and choosing the information to get a solution. Students were not careful in reading and understanding the questions. In solving mathematical literacy problems, students give assumptions to the questions that are not in accordance with the purpose of the problem. So that, students can read the questions properly and correctly but cannot interpret the sentences on the questions. Based on these results, researcher suggest that in the preparation of sentences in mathematical literacy problems, it needs to be emphasized with the right sentence so that the purpose of the problem is well understood by students.

\section{- REFERENCES}

Aini, R. N., \& Siswono, T. Y. E. (2014). Analisis pemahaman siswa SMP dalam menyelesaikan masalah aljabar pada PISA [Analysis of junior high school students' understanding of solving algebra problems in PISA]. Jurnal Ilmiah Pendidikan Matematika, 3(2), 158-164.

Anisah, A., Zulkardi, Z., \& Darmawijoyo, D. (2011). Pengembangan soal matematika model PISA pada konten quantity untuk mengukur kemampuan penalaran matematis siswa Sekolah Menengah Pertama [Development of PISA model mathematical problems in quantity content to measure the ability of mathematical reasoning for junior high school students]. Jurnal Pendidikan Matematika, 5(1).

Asmara, A. S., Waluya, S. B., \& Rochmad, R. (2017). Analisis kemampuan literasi matematika iswa kelas $X$ berdasarkan kemampuan matematika [Analysis of grade $\mathrm{X}$ mathematics literacy abilities based on mathematical ability]. Scholaria, 7(2), 135-142.

Creswell, J. W. (2016). Research Design: Pendekatan Metode Kualitatif, Kuantitaif, dan Campuran [Research Design: Qualitative, Quantitative, and Mixed Methods]. Yogyakarta: Pustaka Pelajar.

Firdaus, F. M., Wahyudin, W., \& Herman, T. (2017). Improving primary students' mathematical literacy through problem based learning and direct instruction. Educational Research and Review, 12(4), 212-219.

Johar, R. (2012). Domain PISA untuk literasi matematika [PISA domain for mathematical literacy]. Jurnal Peluang, 1(1), 30-41. 
Mahdiansyah, M., \& Rahmawati, R. (2014). Literasi matematika siswa pendidikan menengah: Analisis menggunakan desain tes internasional dengan konteks Indonesia [Secondary education student mathematics literacy: Analysis using international test designs with an Indonesian context]. Jurnal Pendidikan dan Kebudayaan, 20(4), 452-469.

Moleong, L. J. (2016). Metodologi Penelitian Kualitatif (Edisi Revisi) [Qualitative Research Method (Revised Edition)]. Bandung: PT Remaja Rosdakarya.

OECD. (2010). PISA 2009 Results: What Students Know and Can Do. Students Performance in Reading, Mathematics and Science (Volume I). Paris: OECD Publishing.

OECD. (2014). PISA 2012 Results: What Students Know and Can Do. Students Performance in Mathematics, Reading and Science (Volume I, Revised Edition, February 2014). Paris: OECD Publishing.

OECD. (2016). PISA 2015 Assessment and Analytical Framework: Science, Reading, Mathematics and Financial Literacy. Paris: OECD Publishing.

OECD. (2016). PISA 2015 Results: Excellence and Equity in Education. Paris: OECD Publishing.

Pietersen, C. (2006). Evaluation of a number skills development programme. South African Journal of Education, 26(3), 413-426.

Prakitipong, N., \& Nakamura, S. (2006). Analysis of mathematics performance of grade five students in Thailand using newman procedure. Journal of International Cooperation in Education, 9(1), 111-122.

Sari, R. H. N. (2015). Literasi matematika: Apa, mengapa dan bagaimana? Seminar Nasional Matematika dan Pendidikan Matematika UNY, 713-720.

Singh, P., Rahman, A. A., \& Hoon, T. S. (2010). The Newman procedure for analyzing primary four pupils errors on written mathematical tasks: A Malaysian perspective. Procedia Social and Behavioral Sciences, 8, 264-271.

Stacey, K. (2011). The PISA view of mathematical literacy in Indonesia. IndoMS: Journal of Mathematics Education, 2(2), 95-126.

Tariq, V., Qualter, P., Roberts, S., Appleby, Y., \& Barnes, L. (2013). Mathematical literacy in undergraduates: Role of gender, emotional intelligence and emotional self-efficacy. International Journal of Mathematical Education in Science and Technology, 44(8), 1143-1159.

Turner, R. (2016). Lesson from PISA 2012 about mathematical literacy: An illustrated essay. PNA, 10(2), 77-94.

Vila, F., \& Sanz, A. (2013). Mathematical literacy in plant physiology undergraduates: Results of interventions aimed at improving students' performance. International Journal of Mathematical Education in Science and Technology, 44(6), 893-904.

White, A. L. (2010). Numeracy, literacy and newman's error analysis. Journal of Science and Mathematics, 33(2), 129-148.

Wijaya, A., Heuvel-Panhuizen, M., Doorman, M., \& Robitzcsh, A. (2014). Difficulties in solving context-based PISA mathematics tasks: An analysis of students' errors. The Mathematics Enthusiast, 11(3), 555-584.

Wulandari, I., Turmudi, T., \& Hasanah, A. (2015). Studi cross-sectional tingkat kemampuan literasi matematis siswa sekolah menengah pertama di Bandung berdasarkan pengujian soal PISA [A cross-sectional study of the level of mathematical literacy ability of junior high school students in Bandung based on PISA problem testing]. Jurnal Lingkar Widyaiswara, 2(3), 10-25. 